\title{
Center za razvoj knjižnic, NUK in vključevanje šolskih knjižnic v COBISS
}

\author{
Library System Development Centre, National and University Library, and \\ integration of school libraries in COBISS
}

\section{Eva Kodrič-Dačić ${ }^{1}$}

IZVLEČEK: Novela Zakona o knjižničarstvu je leta 2015 na novo določila status šolskih knjižnic, Narodni in univerzitetni knjižnici pa naložila naloge, povezane s spremljanjem dejavnosti šolskih knjižnic in njihovim razvojem. Statistično spremljanje dejavnosti šolskih knjižnic, oblikovanje strategije razvoja, koncept triletnih razvojnih načrtov ter razvoj strokovnih podlag za določitev pogojev, ki jih mora izpolnjevati šolska knjižnica na področju vzgoje in izobraževanja, vsebinsko spadajo v delokrog Centra za razvoj knjižnic. Obvezna vključitev šolskih knjižnic v nacionalni bibliografski sistem, ki ga je predpisala novela Zakona, je zaradi velikega števila šolskih knjižnic zahtevala še dodatne aktivnosti. Center za razvoj knjižnic je poleg svoje običajne naloge, povezane z vključevanjem knjižnic v COBISS (določanje sigel), ob finančni podpori MIZŠ šolskim knjižnicam pomagal z informiranjem, svetovanjem pri prevzemanju zapisov iz COBIB.SI, izdelavo priročnikov za identifikacijo, inventarizacijo in izločanje posameznih vrst gradiva ter s centralno katalogizacijo gradiva šolskih knjižnic. Podatki, pridobljeni s statističnimi meritvami, in izkušnje pri centralni katalogizaciji gradiva bodo služili kot izhodišče za racionalno organizacijo obdelave gradiva $v$ šolskih knjižnicah.

KLJUČNE BESEDE: Center za razvoj knjižnic, šolske knjižnice, COBISS

ABSTRACT: The amendments to the Librarianship Act in 2015 redefined the status of school libraries and assigned new tasks associated with the monitoring of the activities and development of school libraries to the National and University Library (NUL). The statistical monitoring of activities performed by school libraries, the designing of the school library development strategy, the concept of three-year development plans and the development of regulations on the conditions to be met by school libraries in the field of education are among the new activities of the Library System Development Centre, NUL. The mandatory integration of school libraries in the national bibliographic system as prescribed by the amendments required additional activities due to the large number of school libraries. In addition to its usual tasks related to the integration of libraries into COBISS (such as assigning the library identification number to each school library), the Library System Development Centre helped school libraries by informing them and by offering advice about downloading bibliographic records from COBIB.SI, and by producing manuals for the identification, accessioning and weeding of individual types of materials; also, it provided central cataloguing of the library material of school libraries; all this was financially supported by the Ministry of Education, Science and Sport. The data obtained through statistical measurements and experience acquired in the central cataloguing of materials will serve as the basis for a rational organisation of processing of materials in school libraries.

KEYWORDS: Library System Development Centre, School libraries, COBISS

Članek je nastal na osnovi prispevka Narodna in univerzitetna knjižnica in vključevanje šolskih knjižnic v COBISS, ki ga je avtorica 27. novembra 2018 predstavila na Konferenci COBISS 2018 v Mariboru.

${ }^{1}$ Doc. dr. Eva Kodrič-Dačić, bibliotekarska višja svetnica, Narodna in univerzitetna knjižnica, Ljubljana, Slovenija, eva.kodricdacic@nuk.uni-li.si. 


\section{Uvod}

Novela Zakona o knjižničarstvu, sprejeta konec leta 2015, je šolske knjižnice tudi v zakonodaji s področja knjižničarstva postavila v kontekst izvajanja javne službe na področju vzgoje in izobraževanja. Novela je določila izdelavo posebnega pravilnika, ki bo določal pogoje za izvajanje knjižnične dejavnosti, potrebne za izvajanje javne službe na področju vzgoje in izobraževanja; $s$ tem je šolskim knjižnicam določila mesto $v$ nacionalnem vzajemnem bibliografskem sistemu, nacionalni knjižnici pa naložila pripravo strokovnih podlag za omenjeni pravilnik, sodelovanje pri pripravi strategije razvoja šolskih knjižnic in njihovih razvojnih načrtov ter statistično spremljanje njihove dejavnosti (Zakon, 2015). Poleg nalog, ki jih je določila novela Zakona o knjižničarstvu, poteka v organizaciji Narodne in univerzitetne knjižnice (NUK) na osnovi akcijskega programa Ministrstva za izobraževanje, znanost in šport (MIZŠ) o vključevanju šolskih knjižnic v COBISS (Kooperativni online sistem in servisi) tudi kreiranje bibliografskih zapisov za gradivo, ki ga imajo ali ki ga pridobijo šolske knjižnice, pa še ni vključeno v COBIB.SI (Vzajemna bibliografska baza podatkov). Velik del zbirk šolskih knjižnic sestavlja identično gradivo, tako da bosta vnašanje in obdelava gradiva v COBISS (dolgoročno) bolj ekonomična in hitrejša.

NUK je začel izvajati nove dejavnosti za šolske knjižnice v okviru Centra za razvoj knjižnic (CeZaR) leta 2016. Nove naloge predstavljajo zahteven izziv, saj je šolskih knjižnic skoraj trikrat več kot knjižnic vseh drugih vrst skupaj. V letu 2017 smo imeli namreč v Sloveniji 1 nacionalno knjižnico, 58 splošnih knjižnic, 88 visokošolskih, 94 specialnih in 683 šolskih knjižnic različnih vrst.

Sredstva za izvajanje novih nalog je NUK-u zagotovil MIZŠ v okviru letnih pogodb z NUK.

Namen prispevka je predstaviti pregled dejavnosti CeZaR na področju šolskih knjižnic v letih od 2016 do 2018, pri čemer bo posebna pozornost namenjena podpori šolskim knjižnicam pri vključevanju v COBISS. $\vee$ zaključku so podani ugotovitve in predlogi za nadaljnje delo, ki so nastali na osnovi triletnih praktičnih izkušenj in podatkov o šolskih knjižnicah, zbranih $v$ tem obdobju.

\section{Statistično spremljanje dejavnosti šolskih knjižnic}

Statistične meritve dejavnosti šolskih knjižnic je do leta 2017 izvajal Statistični urad Republike Slovenije (SURS). Tega leta je CeZaR prvič izvedel meritve dejavnosti šolskih knjižnic, in sicer za šolsko leto 2015/16 (612 poročevalskih enot). Prenos meritev na NUK je sovpadal s težnjami SURS, da resorne meritve prevzamejo za to specializirane organizacije, kar bo zagotovilo bolj kakovostne podatke. Poleg že omenjenih meritev leta 2017 je CeZaR konec leta 2017 izvedel še meritve knjižnic glasbenih šol za šolsko leto 2016/17 (65 poročevalskih enot) in dijaških domov za šolsko leto 2016/17 (13 poročevalskih enot) ter v letu 2018 ponovno meritve knjižnic vseh drugih vrst vzgojno-izobraževalnih zavodov: osnovnih šol, osnovnih šol z vrtcem, osnovnih šol s prilagojenim programom, srednjih šol, zavodov za otroke in mladostnike $s$ posebnimi potrebami ter knjižnic višjih strokovnih šol, in sicer skupaj 615 poročevalskih enot (od tega 453 knjižnic osnovnih šol, 27 knjižnic osnovnih šol s prilagojenim programom, 116 knjižnic srednjih šol, 15 knjižnic zavodov za otroke in mladostnike s posebnimi potrebami in 4 knjižnice višjih strokovnih šol). Meritve bomo tudi v prihodnje izvajali vsaki dve leti, izmenično za posamezne vrste šolskih knjižnic. 
Čeprav podatke, ki jih zbiramo s statističnimi meritvami, potrebujejo tako šolske knjižnice, ki poročajo o obsegu svojega dela, in šole, ki dokazujejo porabo sredstev in kakovost storitev, kot tudi ministrstvo, ki potrebuje podatke za evalvacijo in strateško načrtovanje, so statistične meritve med knjižničarji izredno nepriljubljene. Vprašalniki so obsežni in od knjižničarjev zahtevajo poglobljeno strokovno znanje. Poročevalskim enotam zato poskušamo olajšati izpolnjevanje vprašalnikov s splošnimi navodili o izpolnjevanju vprašalnika, s povezavami na definicije posameznih spremenljivk $v$ vprašalniku in z navodili o načinu zajemanja podatkov iz COBISS, kar je vse zajeto v Priročniku za izpolnjevanje statističnega vprašalnika (Tizaj Marc et al., 2017), ki je dostopen na spletu. Za druge vrste knjižnic že vrsto let pripravljamo tečaj za izpolnjevanje statističnega vprašalnika, kjer knjižnice seznanimo z morebitnimi novostmi v vprašalniku in opozorimo na težave pri zbiranju oziroma izračunavanju vrednosti posameznih spremenljivk. Tak tečaj načrtujemo tudi pred prihodnjimi meritvami šolskih knjižnic. Med meritvami so šolskim knjižničarjem na voljo svetovalci CeZaR za individualno pomoč in svetovanje. Knjižničarji se nanje pogosto obračajo, saj smo pri meritvah dejavnosti šolskih knjižnic v letu 2017/18 v povprečju za vsak izpolnjen vprašalnik knjižnicam svetovali dvakrat, enkrat po telefonu in enkrat pisno.

Letne statistične meritve so gotovo najdražje raziskave na področju slovenskega knjižničarstva. Obsežnost vprašalnika in število poročevalskih enot pomenita na državni ravni več tisoč porabljenih ur. Ob predpostavki, da bi vsaka od 615 poročevalskih enot, ki smo jih pozvali k izpolnjevanju vprašalnika o delu v šolskem letu 2017/18, namenila za izpolnjevanje le 8 ur, to predstavlja skupaj 4.920 ur, čemur je treba dodati še čas in s tem tudi stroške NUK. Zato skušamo omejiti obseg vprašalnika, zmanjšati obremenjenost poročevalskih enot in skrajšati čas meritev.

Zaradi slabe odzivnosti šolskih knjižnic je bila do zdaj izvedba meritev (tabela 1), ki naj bi bila končana $v$ dveh tednih, raztegnjena na dva meseca in več. Upamo, da bomo v prihodnje lahko skrčili nabor podatkov, ki jih zbiramo (to je odvisno od potreb in zahtev deležnikov), in zajemali podatke neposredno iz COBISS, kjer je to seveda mogoče (zbirka, prirast, izposoja).

Pričakujemo, da bodo $v$ naslednjih letih začetne težave $z$ zbiranjem podatkov izzvenele. Začetnim oviram navkljub smo pridobili kakovostne podatke, ki jih potrebujemo za oceno stanja in načrtovanje nadaljnjega dela šolskih knjižnic.

Tabela 1: Statistične meritve dejavnosti šolskih knjižnic

\begin{tabular}{llll}
\hline $\begin{array}{l}\text { Statistične meritve dejavnosti šolskih } \\
\text { knjižnic, izvedene v obdobju 2016-2018 }\end{array}$ & $\begin{array}{l}\text { Število } \\
\text { knjižnic, } \\
\text { vključenih v } \\
\text { meritve }\end{array}$ & $\begin{array}{l}\text { Število } \\
\text { izpolnjenih } \\
\text { vprašalnikov }\end{array}$ & $\begin{array}{l}\text { Delež } \\
\text { izpolnjenih } \\
\text { vprašalnikov (\%) }\end{array}$ \\
\hline šolske knjižnice, 2015/16 & 612 & 577 & 94 \\
\hline knjižnice glasbenih šol, 2016/17 & 65 & 39 & 60 \\
\hline knjižnice dijaških domov, 2016/17 & 13 & 10 & 77 \\
\hline šolske knjižnice, 2017/18 & 615 & 549 & 89 \\
\hline
\end{tabular}

Podatke, pridobljene s statističnimi meritvami, objavljamo neposredno po zaključku meritev na spletni strani CeZaR (Statistični podatki o knjižnicah, 2018), medtem ko potrebujemo za 
objavo analitičnih pregledov meritev (Študije, 2018) in za izračun kazalcev uspešnosti šolskih knjižnic (Kazalci, 2018) še mesec ali dva.

Podatki, ki smo jih zbrali z meritvami, nam bodo služili pri pripravi Pravilnika o pogojih za izvajanje knjižnične dejavnosti, potrebnega za izvajanje javne službe na področju vzgoje in izobraževanja, in pri oblikovanju Strategije razvoja šolskih knjižnic. MIZŠ je v letu 2018 imenoval dve delovni skupini, ki pripravljata dokumenta.

\section{Svetovanje in pomoč pri vključevanju šolskih knjižnic v COBISS}

NUK (CeZaR) sodeluje v procesu vključevanja šolskih knjižnic v sistem COBISS na več področjih. Šolskim knjižnicam, ki so na novo vstopale v sistem, smo dodeljevali sigle, jih informirali in usmerjali, svetovali ter sodelovali na tečajih, ki jih je Zavod za šolstvo organiziral za pomoč šolskim knjižnicam pri prevzemanju zapisov in inventarizaciji gradiva. V letu 2018 smo začeli tudi centralno katalogizacijo knjižničnega gradiva, ki še ni v bazi COBIB.SI, pri čemer je bil poseben poudarek na knjižnicah glasbenih šol in na katalogizaciji notnega gradiva.

Osnovne informacije v pomoč šolskim knjižničarjem, ki se vključujejo v COBISS, so na voljo na spletni strani CeZaR (slika 1).

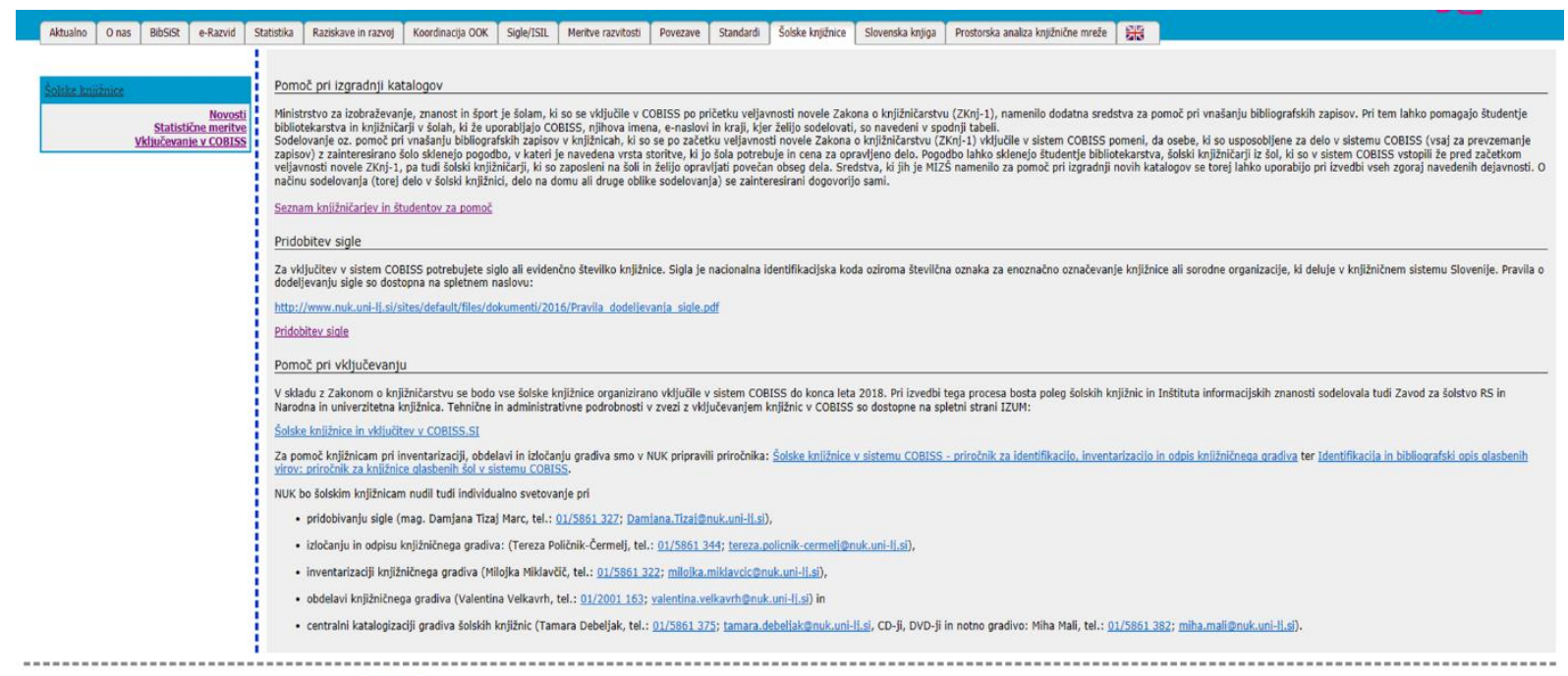

Slika 1: Spletna stran CeZaR z informacijami za šolske knjižnice (Vir: Šolske knjižnice, 2018)

Vstop v COBISS ni mogoč brez sigle in z letom 2016 se je število sigel, ki smo jih dodelili knjižnicam, močno zvišalo. Leta 2016 smo dodelili 36 novih sigel, leta 2017 pa 122 in nato leta 2018 še 74 sigel. V celoti je v naši evidenci sigel 670 šolskih knjižnic (Sigle, 2018). Vključene so šolske knjižnice vseh vrst, tudi knjižnice zasebnih šol in slovenskih šol v zamejstvu.

Šolske knjižnice, ki so se vključevale v COBISS, so se le redko obračale na NUK za pomoč pri katalogizaciji, inventarizaciji in odpisu gradiva. Zato smo zanje izdelali dva priročnika: Šolske knjižnice v sistemu COBISS: priročnik za identifikacijo, inventarizacijo in odpis knjižničnega gradiva avtoric Tereze Poličnik-Čermelj in Valentine Velkavrh (2016), ki je od leta 2017 prosto dostopen na spletni strani CeZaR, ter Identifikacija in bibliografski opis glasbenih virov: priročnik za knjižnice glasbenih šol v sistemu COBISS avtorice Alenke Bagarič (2017), ki je 
namenjen predvsem knjižnicam glasbenih šol in je bil na spletni strani objavljen v začetku leta 2018.

Tereza Poličnik je tematiko identifikacije, inventarizacije in odpisa gradiva predstavila tudi na tečajih Zavoda za šolstvo, ki so bili organizirani v podporo šolskim knjižnicam pri vključevanju $\checkmark$ COBISS.

Ker je MIZŠ zagotovil finančno pomoč knjižnicam pri vključevanju v COBISS, smo na spletni strani objavili seznam pomočnikov. V maju 2018 smo v NUK začeli centralno katalogizacijo gradiva šolskih knjižnic, ki še ni vključeno v COBIB.SI. Posebna pozornost je bila namenjena knjižnicam glasbenih šol, saj je MIZŠ zagotovil sredstva za zaposlitev katalogizatorja za notno gradivo. Do konca leta se je v centralno katalogizacijo vključilo 61 knjižnic (od tega 10 knjižnic glasbenih šol) iz 10 statističnih regij, izostale so le šole iz Pomurske in Posavske regije (tabela 2). $V$ tem času so knjižnice $v$ NUK poslale 2.891 naslovov gradiva, katalogizatorja pa sta kreirala 1.015 bibliografskih zapisov za monografske publikacije, 1 zapis za serijsko publikacijo, 836 zapisov za muzikalije in 79 zapisov za drugo neknjižno gradivo. Izdelanih je bilo 883 normativnih zapisov, 26 zapisov je bilo redigiranih.

Tabela 2: Število sodelujočih šol knjižnic po statističnih regijah, 1. 5.-31. 12. 2018 (Vir: Tamara Debeljak (NUK))

\begin{tabular}{llll}
\hline Statistična regija & $\%$ & $\begin{array}{l}\text { Število } \\
\text { sodelujočih šol }\end{array}$ & Število vseh šol \\
\hline Gorenjska & 8 & 5 & 64 \\
\hline Goriška & 11 & 5 & 47 \\
\hline Jugovzhodna Slovenija & 10 & 6 & 57 \\
\hline Koroška & 7 & 2 & 28 \\
\hline Obalno-kraška & 13 & 5 & 39 \\
\hline Osrednjeslovenska & 15 & 25 & 164 \\
\hline Podravska & 2 & 3 & 127 \\
\hline Pomurska & 0 & 0 & 58 \\
\hline Posavska & 0 & 0 & 37 \\
\hline Primorsko-notranjska & 19 & 5 & 26 \\
\hline Savinjska & 3 & 3 & 96 \\
\hline Zasavska & 11 & 2 & 18 \\
\hline
\end{tabular}

\section{Posebnosti šolskih knjižnic}

Šolske knjižnice so v preteklih treh letih zmogle izjemen premik. Konec leta 2015 je bilo v COBISS vključenih 172 šolskih knjižnic, konec leta 2018 pa 625. Kako veliko delo je bilo v teh treh letih opravljeno, nam ne govori le število šolskih knjižnic, ki so se vključile v COBISS, temveč tudi specifične okoliščine, v katerih šolske knjižnice delujejo. Čeprav je težko primerjati različne vrste knjižnic, podatki, pridobljeni iz statističnih meritev in drugih raziskav, kažejo, da so zaposleni v šolskih knjižnicah močno obremenjeni.

V šolskih knjižnicah je bilo po podatkih BibSiSt online (Statistični podatki o knjižnicah, 20152016) v šolskem letu 2015/16 zaposlenih 813 oseb, ki so skupaj predstavljale 455,46 polnih zaposlitev (ekvivalent polne zaposlenosti). Manj kot enega ali enega zaposlenega je imelo 495 knjižnic (80 \%) od 612 knjižnic, 67 šol pa naj sploh ne bi imelo zaposlenih na delovnem mestu knjižničarja. Zbirka knjižničnega gradiva je presegala 8.600 .000 enot, kar šolske knjižnice po 
obsegu knjižničnih fondov uvršča na drugo mesto med knjižnicami, takoj za splošnimi knjižnicami (s knjižnično zbirko 11.700 .000 enot leta 2015) in pred visokošolskimi knjižnicami (s knjižnično zbirko 5.200 .000 enot leta 2015). V šolskem letu 2015/16 so šolske knjižnice beležile prirast 267.000 enot ( $v$ letu 2015 so splošne knjižnice skupaj beležile prirast 433.000 enot, visokošolske knjižnice pa 126.000 enot) in imele 276.000 članov (splošne: 479.000, visokošolske: 108.000). Podatki, preračunani na ekvivalent polne zaposlenosti, kažejo na veliko obremenjenost šolskih knjižničarjev/k. Šolski knjižničar/ka skrbi za 10.600 enot zbirke ( $v$ splošnih za 8.500, v visokošolskih pa za 12.000) in 329 enot letnega prirasta, kar je več kot v splošnih (314) in v visokošolskih (290) knjižnicah. Tudi po številu članov na polno zaposlenega delavca (339) so močno obremenjeni/e (splošne: 347, visokošolske: 249) (Kazalci, 2015/2016).

Podrobneje nam je stanje v šolskih knjižnicah osvetlila anketa o nalogah šolskih knjižničarjev/k. Vprašalnik s 45 vprašanji in 132 spremenljivkami smo poslali na 807 naslovov knjižničarjev/k vseh vrst knjižnic, razen knjižnicam dijaških domov. Anketa je trajala od 4. do 18. 7. 2018 in v tem času je bilo ustrezno izpolnjenih 432 vprašalnikov. Želeli smo ugotoviti, kakšne so značilnosti šolskih knjižničarjev/k in kakšna je dostopnost šolske knjižnice, ter dobiti podrobnejše podatke o vsebini dela in težavah, s katerimi se šolske knjižnice srečujejo. Tudi iz teh odgovorov lahko povzamemo, da za večino knjižnic skrbi le en zaposleni ali celo manj (kadar delež zaposlitve na mestu knjižničarja ne dosega 100 \%). Šolska knjižnica je v povprečju odprta 24 ur tedensko, pri čemer 83 (22\%) od 372 anketirancev, ki so odgovorili na vprašanje, nima določenega časa odprtosti oziroma je ta deljen. Poleg knjižničarskih del, ki predstavljajo v povprečju 59-odstotni delež celotne zaposlitve, in dejavnosti, povezanih z učbeniškim skladom (12,5\%), predstavljajo skoraj $30 \%$ naloge, povezane z vzgojno-izobraževalnim delom zavoda (21,3\%), ter druge dejavnosti (7,2 \%).

Zato ne preseneča, da je več kot polovica knjižničarjev/k menila, da 40-urna delovna obveznost ne zadošča za kakovostno izvedbo knjižničarskih del. Od 337 anketirancev jih je tako odgovorilo 183. Med temi jih je le 20 ( $6 \%$ vseh, ki so odgovorili na to vprašanje) kot razlog za preobremenjenost navedlo vključevanje $v$ COBISS.

Sicer pa knjižničarje/ke pri delu $v$ šolski knjižnici najbolj motijo neustrezni normativi, podcenjujoč odnos (pedagoških) sodelavcev in vodstva šole do knjižničarjev/k in knjižničarskega dela, preveč nalog, nadomeščanje učiteljev in različne oblike varstva učencev ter nedefiniranost knjižničarjevega dela, tako glede vsebine kot tudi števila ur, ki jih mora knjižničar/ka opraviti. Obvezni prehod na sistem COBISS je kot moteč dejavnik izpostavilo le $8 \%$ oziroma 25 od 310 anketirancev, ki so odgovorili na vprašanje, kaj jih pri delu najbolj moti.

\section{Izzivi šolskih knjižnic}

Število šolskih knjižnic, ki so se v letih od 2016 do 2018 vključile v COBISS, govori o velikem angažmaju šolskih knjižnic in o njihovi pripravljenosti na sodelovanje ter tudi o pripravljenosti vseh drugih institucij, ki so sodelovale v tem projektu (MIZŠ, IZUM, Zavod za šolstvo, NUK). Vključevanje v nacionalni vzajemni bibliografski sistem je bil le eden od izzivov, pred katerega so bile šolske knjižnice postavljene v zadnjih nekaj letih. Poleg tega so se morale soočati tudi z upravljanjem učbeniškega sklada, izločanjem gradiva, večjo obremenjenostjo zaradi sprememb v šolskem sistemu in perečim problemom neustreznih normativov. Bolj, kot smo se ukvarjali s problematiko šolskih knjižnic, več kot smo zbrali podatkov, bolj jasno so bile zarisane težave - in vedno več jih je bilo. 
Ob vključevanju šolskih knjižnic v COBISS smo izhajali iz predpostavke, da je večji del fondov šolskih knjižnic identičen. Vendar je šolskih knjižnic veliko, zato je tudi veliko specifičnega, unikatnega gradiva. Ne gre le za tuje publikacije, pač pa tudi za raziskovalne naloge, članke, zaključna dela, notno gradivo in didaktične pripomočke, ki jih knjižnice vključujejo v svoje fonde. Prav tako imajo šolske knjižnice specifične zahteve pri popisu gradiva (na primer popis elementov zbirk pri notnem gradivu). Zato bomo tudi $v$ prihodnje morali poskrbeti za centralno katalogizacijo gradiva in obenem razmisliti o tem, kdaj obseg unikatnega gradiva $v$ šolski knjižnici zahteva bibliotekarja z dovoljenjem za vzajemno katalogizacijo.

\section{Reference}

Bagarič, A., 2017. Identifikacija in bibliografski opis glasbenih virov: priročnik za knjižnice glasbenih šol v sistemu COBISS. Ljubljana: Narodna in univerzitetna knjižnica. Dostopno na: https://cezar.nuk.uni-lj.si/analize/studije.php [24. 11. 2018].

Kazalci. BibSiSt online, 2018. Dostopno na: https://bibsist.nuk.uni-lj.si/kazalci/kazalci sol.php [24. 11. 2018].

Poličnik-Čermelj, T. in Velkavrh, V., 2016. Šolske knjižnice v sistemu COBISS: priročnik za identifikacijo, inventarizacijo in odpis knjižničnega gradiva. Ljubljana: Narodna in univerzitetna knjižnica. Dostopno na: http://cezar.nuk.unilj.si/common/files/studije/solske knjiznice cobiss.pdf [24. 11. 2018].

Tizaj Marc, D., Kodrič Dačić, E., Vodeb, G., Bahor, S., Bon, M., Lesjak, B. et al., 2017. Priročnik za izpolnjevanje statističnega vprašalnika. Ljubljana: Narodna in univerzitetna knjižnica.

Dostopno na: https://cezar.nuk.unilj.si/common/files/metodologija/prirocnik za meritve.pdf [24. 11. 2018].

Sigle. Center za razvoj knjižnic - CeZaR, 2018. Dostopno na: https://cezar.nuk.unili.si/sigle/index.php [24. 11. 2018].

Statistični podatki o knjižnicah. BibSiSt online, 2018. Dostopno na: https://bibsist.nuk.unilj.si/statistika/index.php [24. 11. 2018].

Šolske knjižnice. Center za razvoj knjižnic - CeZaR, 2018. Dostopno na: https://cezar.nuk.unilj.si/solske/cobiss.php [24. 11. 2018].

Študije. Center za razvoj knjižnic - CeZaR, 2018. Dostopno na: https://cezar.nuk.unilj.si/analize/studije.php [24. 11. 2018].

Zakon o spremembah in dopolnitvah Zakona o knjižničarstvu (ZKnj-1a), 2015. Uradni list RS, št. 92. 